\title{
Why is the Medical Symbol a Snake?
}

\begin{abstract}
Tıbbın Sembolü Neden Yılan?
(D) Ekrem Güner ${ }^{1}$, (D) Kamil Gökhan Șeker¹, (D) Șebnem İzmir Güner²

Keywords: Asclepius, Hermes, Caduceus, Medicine, Snake, Symbol, Coin

\section{Introduction}

Nowadays, health-related professions and institutions are symbolized with an illustration of a snake wrapped around a branch of a tree, a stick or a rod. Although there are various animals that have protective instincts for humans or that can communicate with human beings, an association has been accepted to be present between health and this unpleasant and cold creature. Indeed, it is difficult to find any other creature other than the snake that has been attributed such negative meanings. It was once considered a God and was expected to offer remedies (1-3), and then was regarded as a scary creature that could kill humans with its poison.
\end{abstract}

1University of Health Sciences, İstanbul Bakırköy Dr. Sadi Konuk Training and Research Hospital, Clinic of Urology, İstanbul, Turkey

2Esenyurt University, Memorial Șișli Hospital, Clinic of Internal Medicine and Hematology, Istanbul, Turkey öz

Günümüzde sağlıkla ilgili meslekler ve kurumlar, dal, sopa veya asaya sarılmış yılan resmiyle sembolize edilmektedir. Bu yazımızda antik çağdan itibaren insanı etkilemiş, efsane ve mitolojilerde geçmiş, antik dönem rölyef, heykel ve sikkelerde resmedilmiş, yazılı metinlere girmiş olan yılanın neden sağlı̆̆ın ve tıbbın sembolü olarak seçildiğini antik dönem arkeolojik sikke görselleri eşliğinde ortaya çıkarmaya çalışacağız.

Anahtar Kelimeler: Asklepios, Hermes, Kadukeus, Tıp, Yılan, Sembol, Sikke
The snake has influenced mankind since ancient times and has been given a place in legends and mythologies. It was also depicted in ancient age reliefs, statues and coins, and was included in written texts. In this article, we are going to discuss in the light of ancient age coin visuals why the snake is accepted as the symbol of health and medicine.

He was also depicted in antique reliefs, sculptures and coins, and was included in written texts. In this article, we will discuss why the snake is considered a symbol of health and medicine in the light of ancient coins.

\section{Discussion}

Snake is different from other animals, as it can slough its skin off, move fast despite the absence of feet and live underground, above the ground and under water $(1,4)$. Thanks to these characteristics, it has attracted the attention of mankind since ancient times, and it has been regarded to be holy and protecting, respected with slight fear, and even worshipped to it. (5).

Throughout history, the snake has been attributed several features such as renewal, youth, fertility, medicine, long life, immortality, common sense, precaution, physical power, potency, wisdom, farsightedness, prophecy, good luck and speed (5-10). The main reason for the association of snake with health is that it gets renewed and rejuvenated by sloughing its skin off. This is a process that symbolizes the metamorphosis among birth, life and death (4,6,11-13). Furthermore, as an animal that can live underground, above the ground and under water, snake is deemed to be a creature which knows the best about the healing power of nature that is evident in natural spring waters, flowers and herbs and thus, the symbol of health and medicine is attributed to it (14).

It is not known exactly where and when the snake first appeared in mythologies and legends, but it is observed to have taken a significant 
role in the Eastern and Asian mythologies since 3000 B.C. Mesopotamian workpieces and structures belonging to 2800 B.C. have reliefs and legends about snakes. The most important of these is the Epic of Gilgamesh. A snake took away the jiaogulan that a hero named Gilgamesh took out of the water. Once the snake ate this plant, it sloughed its skin off and rejuvenated $(5,15)$.

Snake is also important in the Egyptian mythology and it has preserved the holy city, Thebai. Thebai is the most prominent health center in ancient Egypt and its totem is a snake (16).

The ancient Greek world had some beliefs and mythologies from Mesopotamia and Egypt, and it accepted the snake as the symbol of eternal life. Asclepius, The God of medicine, was often portrayed in statues, reliefs and coins as experienced and at adult age, accompanied with a snake wrapped around a branch symbolizing the tree of life $(17,18)$ (Figure 1a). This branch is his rod and the snake is usually depicted as wrapped around it $(19,20)$ (Figure 1b). Images of isolated snakes with head up and moving forward in curls mainly symbolize the Asclepius (Figure 1c). The word Asclepius is thought to be derived from the word "askalabos", which means "snake" in Greek $(14,21)$

As the symbol of Asclepius, which is a snake, is believed to possess eternal youth as it sloughs its skin off, it was directly associated with health in the ancient Greek world (5). Asclepius was claimed to take its healing power from the snake and the people offered their vows not to Asclepius but to the snake, indeed. When Asclepius became the God of medicine over time, the figure of a snake wrapped around the accessory of the God, which is the rod, became the symbol of his healing power (22-24).

Asclepius was represented as an old and trustable man with a rod in his hand. This shows that medical education will not be short and that the training and practice processes will last so long that one will grow old and hold a rod for support. According to Asclepius, the God of medicine and health, a doctor must also be as quiet as a snake, must not reveal anyone's secret to others, and work in patience and calmness.

There is no evidence about Caduceum (Figure 2), which is a doubleheaded snake figure wrapped around the winged rod, Caduceus (25),

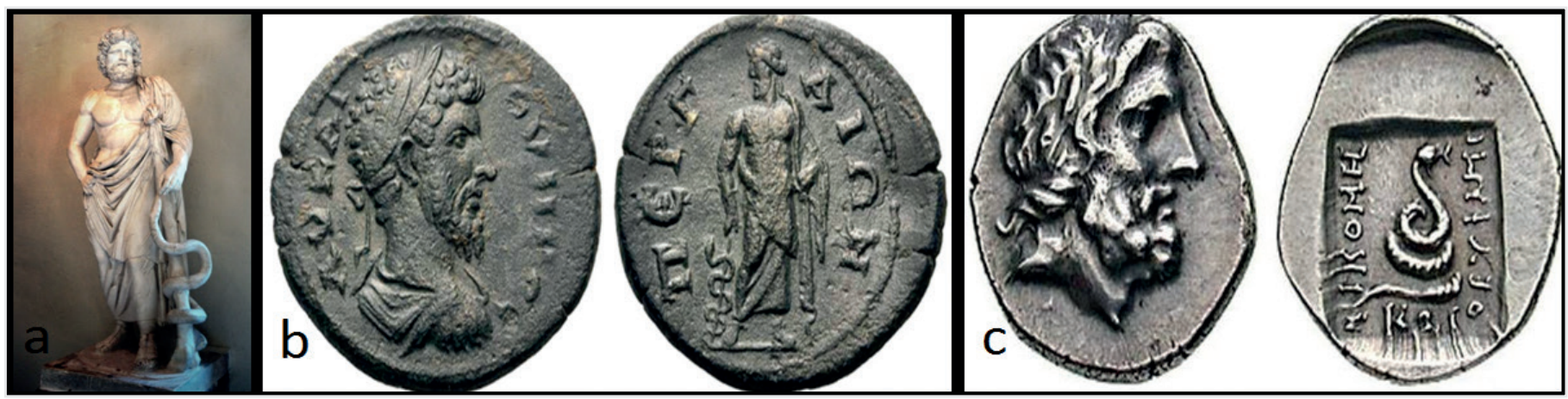

Figure 1. a) Asclepius with his serpent-entwined staff, Archaeological Museum of Epidaurus, Greece,

b) The Roman period, Turkey, Asia Minor, Pamphylia Region, Bronze coin issued in Perge city from 161 to 180 B.C. Front side: Daphne crowned, bearded Emperor Marcus Aurelius. Back Side: The God Asclepius is standing holding his rod wrapped with a snake,

c) The Hellenistic period, Greece. Silver tetrobol issued in Kos Island from 167 to 88 BC. Front side: Daphne crowned, bearded God Asclepius. Back side: Coiled snake with its head up

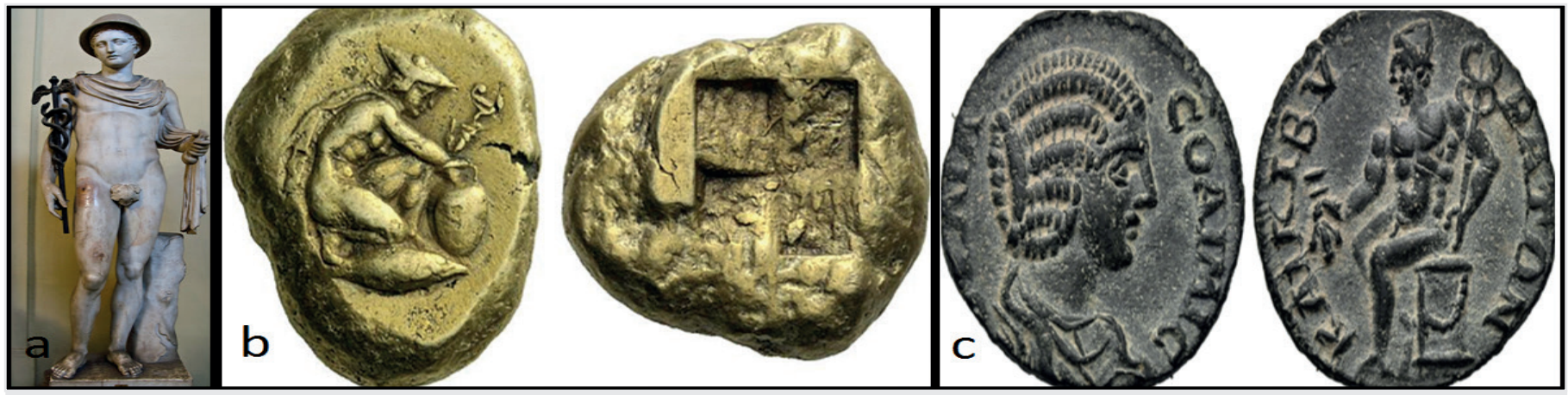

Figure 2. a) Statue of Hermes, From the Musei Vatican Museum, Rome, Italy,

b) The Hellenistic period, Turkey, Asia Minor, Mysia Region. Golden stater issued in Kyzikos town from 460 to 400 B.C. Front side: God Hermes, holding caduceus with his left hand. Back side: Quadripartite incus,

c) The Roman period, Turkey, Asia Minor, Phyrgia Region. Bronze coin issued in Kibyra town from AD 218 to 222 . Front side: Julia Soaemias. Back side: God Hermes is sitting, holding caduceus in his left hand 
which belongs to another Greek God, Hermes (Mercury in Greek) (Figure 3a). In Europe, only at the end of the Middle age and in early Renaissance age, the double-headed snake wrapped around the winged rod of Hermes began to be used as a symbol associated with health (18,26-29). The first official use of Caduceum is claimed to be by the US Marine Service (29) (Figure 3b).

According to a research conducted in the US in 1992, 62\% of professional medical institutions were using the snake wrapped around the rod of Hermes as a symbol, and medical commercial institutions were using the double-headed snake wrapped around Hermes' Caduceus (30) as their symbol.

However, double-headed snake figure of God Hermes is mostly not used by medical associations in Greece. Instead, the snake figure of God Asclepius that was originated from mythology serves as a symbol for several Greek medical associations (28).

Today, the single snake wrapped around the rod of Asclepius and the double-headed snake wrapped around the winged rod of Hermes are accepted as the symbols of medicine. Consequently, the common figures of both Gods, which are the snakes wrapped around a rod, were adopted as the symbol of health by health-related professions and institutions and they used these in their logos. The figure of snake wrapped around a rod, which takes place in the logo of the World Health Organization, draws attention to the fact that it is very similar to the figure of snake wrapped around a rod, which was illustrated on ancient coins (Figure 4).

\section{Conclusion}

Snake, which has been mentioned in legends, epics and mythologies since 3000 B.C. and which has taken place in visual or written form in ancient age statues, reliefs, coins and texts has appealed and influenced the humankind for centuries. Since the ancient Greek age, the reason for the snake to be accepted as the symbol of health has been explained in the light of the characteristics attributed to snake.

The snake's sloughing its skin off sort of means the renewal of life and rejuvenation. Throughout history, the snake has been attributed several features such as power, speed, farsightedness, good luck, healing, health and long life which are associated with the occupations that offer health and it highly deserves being the symbol of health and medicine considering the fact that even its poison is healing for the humankind.

Whether wrapped around the rod of Asclepius or Hermes, all the heroes of medicine proudly wear those snakes on their collars today as their own symbols.

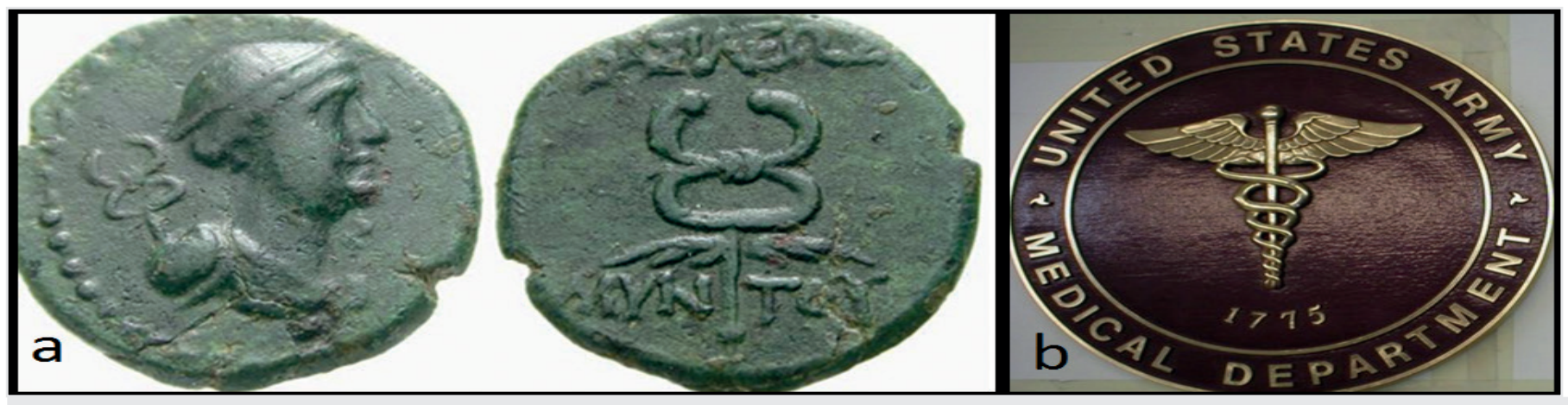

Figure 3. a) The Early Roman period, Turkey, Asia Minor, Galatia Region. Bronze coin issued from 37 to 25 B.C. Front side: Hermes, wearing a hat and caduceus on his shoulder. Back side: Winged Caduceus (kerykeion),

b) U.S Army Medical Department logo

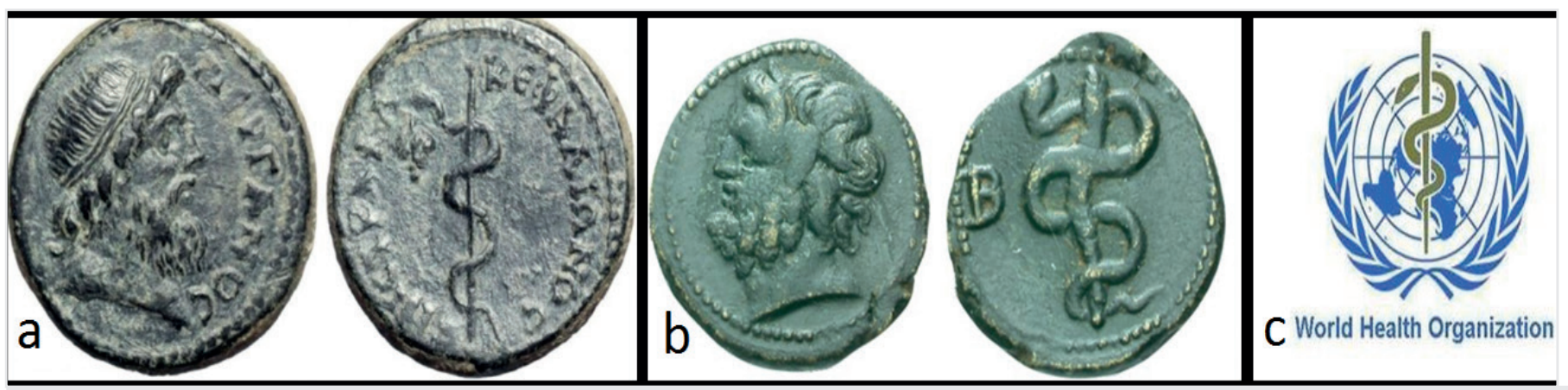

Figure 4. a) The Early Roman period, Turkey, Asia Minor, Mysia Region, Bronze coin issued in Pergamon town from AD 100 to 200. Front side: Pegamos wearing a hat. Back side: A snake wrapped around a rod,

b) The Hellenistic period, Turkey, Asia Minor, Mysia Region, Bronze coin issued in Pergamon town in 131 B.C. Front side: Daphne crowned, bearded God Asclepius. Back side: A snake wrapped around a rod,

c) The remarkable similarity between the logo of the World Health Organization (WHO) and the snake wrapped around the rod of Asclepius 


\section{References}

1. Armutak A. Animal paterns in the Eastern and Western Mythologies II. Reptiles, Fish, Avians and Mythological Animals. J Fac Vet Med Istanbul Univ 2004; 30: 143-57.

2. Hançerlioğlu 0. İnanç Sözlüğü. Remzi Kitabevi İstanbul; 1975. pp.1-861.(In Turkish)

3. Yondemli F. Tarih öncesinden günümüze yılan. Piramit yayıncılık; Ankara. 2004. (In Turkish)

4. Menez A. The subtle beats, Snakes from Myth to Medicine. New York: TaylorFrancis 2003; V4.

5. Campbell J. Doğu Mitolojisi, (Çev: Kudret Emiroğlu). Imge Yay Ankara; 1993.p.38. (Turkish Translate)

6. Lurker M (ED.) Snakes. In: Dictionary of gods and goddesses, devils and demons. London: Routledge. 1989. (transl. by M. O'Connell).

7. Hendel R Serpent. In: K. van der Toorn (ed.), Dictionary of deities and demons in the Bible. Leiden, New York, Köln: E.J. Brill; S 1995. pp. 1404-12.

8. Christy NP. On fear of serpents and ophiolatry. Trans Am Clin Climatol Assoc 1968; 79: 21-33.

9. Okuda J, Kiyokawa R. Snake as a symbol in medicine and pharmacy- a historical study. Yakushigaku Zasshi 2000; 35: 25-40.

10. Williams NW. Serpents, staffs, and theemblems of medicine. HolyBible, Genesis, Chapter 3, OldTestament.JAMA 1999.pp.281-475.

11. Allen $\mathrm{N}$. The healing serpent in the Judaeo-Christian tradition. In: S. Kottek\&H.F.J. Horstmanshoff (eds.), From Athens to Jerusalem. Rotterdam: Erasmus, 2000.pp. 203-25.

12. Bunn J T. Origin of the caduceus motif. JAMA 1967; 202: 615-9.

13. Lawrence C. The healing serpent-the snake in medical iconography. Ulster Med J 1978; 47: 134-40.

14. Rosenberg D. Dünya Mitolojisi. 4. Baskı. Ankara: İmge Kitabevi, 2006. (In Turkish)
15. Jackson, D. Gılgamış Destanı, Cev. Ahmet Antmen, Ankara: Arkadaş Yayınevi. 2013. (In Turkish)

16. Yöndemli, Fuat, Hayat ağcı ejder yılan. Nüve Kültür Merkezi ,ístanbul. 2006 (In Turkish)

17. Nayernouri T. Asclepius, Caduceus, and Simurgh as medical symbols, part I. Arch Iran Med 2010; 13: 61-8.

18. Blaeyney K. The Caduceus vs. the Staff of Asclepius. 2005.

19. Bohigian GM. The staff and serpent of Asclepius. Mo Med 1997; 94: 210-1.

20. Wilcox RA, Whitham EM. The symbol of modern medicine: why one snake is more than two. Ann Intern Med 2003; 138: 673-7.

21. Kellie SM. Cult of Asclepius. The Lancet 1999; 354: 1038.

22. Leventi I. The iconography of Health in the classical years. Athens: Hellenic National Archive of Documents, 1991.p. 137.

23. van Straten F. Votives and Votaries in Greek Sanctuaries. In: Greek Religion. Ed. Buxton RGA. London: Oxford University Press, 2000.pp.247-90.

24. Caton R. The Temples and ritual of asklepios. $2^{\text {nd }}$ Ed. London: C. J. Clay and Sons, 1900.

25. Larose C. The caduceus v. the staff of aesculapius. Can Med Assoc J 1979; 121: 158.

26. Retief FP, Cilliers L. History of medicine: snake and staff symbolism, and healing. S Afr Med J 2002: 92: 553-6.

27. Schouten J. The rod and serpent of Asklepios. Amsterdam, Elsevier, 1697. pp 107-116.

28. Antoniou SA, Antoniou GA, Learney R, Granderath FA, Antoniou Al. The rod and the serpent: history's ultimate healing symbol. World J Surg 2011; 35: 217-21.

29. Hart GD. The earliest medical use of the caduceus. Can Med Assoc J 1972; 107: 1107-10

30. Friedlander WJ. The Golden Wand of Medicine. New York: Greenwood Press; 1992. 